\title{
MILITARY TENSIONS ACROSS THE LINE OF CONTROL: IMPLICATIONS FOR LOCAL POPULATION IN PAKISTAN-ADMINISTERED KASHMIR
}

\author{
Sohail Akhtar \\ Lecturer at National University of Modern Languages, Islamabad. \\ Sohail.akhtar@numl.edu.pk \\ Sadat Hassan Bilal \\ Visiting Faculty at Quaid-I-Azam University, Islamabad. \\ saadathassan@ir.qau.edu.pk
}

\begin{abstract}
'Kashmir' has been an issue between Pakistan and India and there has been a struggle over Kashmir between the two nuclear-armed states since they got portioned. There is enough literature available on the Kashmir issue, but the Pakistan-administered Kashmir has been neglected, especially the local population across the Line of control. It is the local population that bears the brunt of across-theborder tensions. Across the border tensions have become a norm, the local population has to suffer a lot. The mainstream media on both sides of the Line of Control looks at this conflict with a popular discourse that prevails. For International states, for example, the United States, India, and Pakistan is a flashpoint, both are nuclear-armed, any severe escalation can give rise to a larger conflict that would be dangerous for this whole region. In all this debate the Local Kashmiris on LoC are excluded. Mainstream media reduces the miseries of the local population in numbers but the scar on them is long-lasting. This paper intends to analyze and focus on implications of across-the-border (LoC) tensions on the local population in Pakistan-administered Kashmir. What socioeconomic cost, the population very close to the border bear? How much have they been suffering and suffering in general during the heightened tensions across the border? How has the State responded to this situation? What the latest truce agreement on LoC means for the locals in AJK? To analyze the problem this study aims to do qualitative research, focused on a local population especially the villages very close to the line of control ( $\mathrm{LoC}$ ).

Keywords: Tensions along the Line of Control, Azad Jammu and Kashmir/ Pakistan-administered Kashmir, Local Population across the LoC, implications of Cross LoC firing on local people in AJK, Front-line dynamics, Autonomous Military Factors, Inadvertent Crossing, Jihadist infiltration, Militancy, and tangled politics.
\end{abstract}

\section{INTRODUCTION}

The Kashmir conflict is as old as the history of Pakistan. In August 1947 India and Pakistan emerged on the world map as two separate independent states. Kashmir being the largest among the independent 562 princely states, did not join either of the two dominions but the later events proved detrimental to the sovereignty of the then State of Jammu and Kashmir. Political forces opposite to Maharaja Hari Singh in Poonch present-day AJK by joining tribe's men from Khyber Pakhtunkhwa (KP) province marched to Srinagar in October 1947. To avert that situation, Maharaja Hari Singh asked India for military protection. India offered him military protection on the condition of signing an agreement which Hari Singh accepted provisionally. India termed that document as an accession letter but for Pakistan, it was not acceptable. The situation between the two dominions further conflagrated and they fought a full-scale war in 1948.

There is a history of the strained relationship between India and Pakistan, a long span of heightened tensions dominated the relationship between the two with rare chances of normalcy and peace. On January 1, 1949, India and Pakistan ended the war, withdrew all the troops, and agreed upon a ceasefire mediated by United Nations (UN). It established a ceasefire line known as the Line of Control (LoC). Operation Gibraltar was started by Pakistan on August 5, 1965, to liberate Indian Occupied Kashmir and in 1971, fighting erupted in East Pakistan. It ended with the Shimla agreement, establishing the LoC between India-controlled Kashmir and Pakistan-controlled Kashmir. But arguing over the border continued. 
Struggle for Independence and the Right to self-determination continued by the Kashmiris. Elections of 1987 in Kashmir were managed and rigged by the Indian government that gave rise to armed struggle. As a result of that thousands of people got killed. In 1999, Kargil Conflict gave rise to limited war. There have been some moments when we have witnessed the proverbial war and peace situation. A six-month ceasefire was ended by India on May 23, 2001, subsequently invited General Pervez Musharraf to peace talks. Atal Bihari Vajpayee and Musharraf met in Agra, India on 14-16 July for a three-day summit but the talks failed.

There have also been some efforts for peace by the two states, for example in November 2003, India agreed to a Pakistani offer of a ceasefire and on January 4, 2004, Indian Prime Minister Vajpayee met with President Musharraf in Islamabad. Diplomats and secretary-level meetings were also held in 2006 and 2007. The Trade route was opened on the LoC on October 28, 2008, but the Mumbai terror attacks that happened in 2008 dashed the peace efforts. After some time, the peace talks resumed in 2011. Asif Ali Zardari met with Man Mohan Singh on April 8, 2012. In 2014 elections were held in India and Bhartiya Janata Party (BJP) came into power. Indian army base in Uri about (102 kilometers) from Srinagar was attacked by the militants on 18 September 2016.

From 2016 ceasefire violations (CFVs) in Kashmir had increased and triggered even more in 2017. Figures quoted by the government of India to the Lok Sabha showed that 881 ceasefire violations took place in Kashmir in 2017, compared to only 449 in 2016. Of these 881 incidents, 110 occurred along the international border (which Pakistan calls the working boundary) and 771 along the LoC.

On the other hand, stats provided by Pakistan in October 2017showed even higher CFVs. The Media wing of Pakistan armed forces inter-services public relations office (ISPR), quoted 1,140 violations in 2017, compared to just 382 in 2016. Director-General of Military Operations (DGMO) recorded 1,299 CFVs in 2017, figures provided by the ISPR showed 'Highest CFVs in 2017 any other year since 2003' that is the date of the last ceasefire agreement between India and Pakistan.(Jaffrelot, 2018).

Escalation and tension on LoC continued since 2016, in 2018, the CFVs were even higher than in 2017. Nirmala Sitharaman, the Indian defense minister told the Rajya Sabha that 1,432 CFVs had taken place, including 942 along the LoC and 490 along the international boundary. An increase in casualties was also reported. Thirty people got killed on the Indian side in 2017, and forty-five on the Pakistani side (compared to forty-six total in 2016) (Research, 2020).

On February 14, 2019, a convoy of Indian paramilitary personnel was hit by a local suicide bomber. India blamed Pakistan and threatened action. A military standoff happened, and across the border, tensions heightened. Many civilians got killed, and a large number of populations were shifted temporarily to other areas far away from the border.

There are multiple explanations for ceasefire violations. They range from local to political. Indian Journalist and professor Happymon Jacob are of the view that front-line dynamics are an important factor. It is not necessarily commanded, planned, and directed from the military headquarters of both states. Autonomous military factors, escalation dynamics, and border management issues are the main reasons for CFVs. Political factors include cross-border infiltration/ inadvertent crossings and local politics.

There are socio-economic implications of across-the-border tensions in Kashmir on the local population. There is a psychological and economic toll. Many people have been killed, displaced, and socially and economically affected. Educational and other infrastructure has been destroyed. Many schools remain closed for a long time, trade across the LoC is suspended. Basic human rights and digital rights are violated. Most of this goes unreported in mainstream media, even such a human toll on Kashmiris makes it to the news, and they do not capture the sufferings and miseries an average Kashmiri living close to the border goes through.

\section{Historical Background}

History is very often a contested terrain; the history of Kashmir is also the same. It is relevant to the topic of study to mention here the origin of conflict. The official narratives of India and Pakistan about Kashmir are maximalist. India considers Kashmir as its important part while for Pakistan it is the 
jugular vein. According to the partition plan of $3^{\text {rd }}$ June 1947, Muslim majority areas were destined to be part of Pakistan and Hindu majority areas were to join India, but it did not happen. Moreover, due to geographical proximity and cultural affinity with Pakistan, it was feasible for Kashmiris to join Pakistan. There were no such things in the case of India (Snedden, 2013).

Jammu and Kashmir's economic and communication links were established with western Punjab and KP province of Pakistan, geographically and economically it was feasible for Kashmiris to join Pakistan. Maharaja Hari Singh was ambivalent, a Hindu ruler of a Muslim-majority State of Jammu and Kashmir was unable to consider joining the Muslim Majority Pakistan. Different political aspirations of the people of Kashmir, divisions based on faith, and even the divisions among the Muslims compelled Maharaja to vacillate.

Srinagar and the Valley of Kashmir were dominated by the Muslims and were led by Sheikh Mohammad Abdullah while others in the Present-day AJK were led by Choudhary Ghulam Abbas, Sardar Ibrahim, Abdul Qayyum Khan in opposition to Sheikh Abdullah. People in Poonch Jaghir were strongly opposed to the despotic rule of Hari Singh, they revolted against his rule. Jammu region was dominated by Hindu Pandits and communal violence was also brewing. These factors posed a dilemma-like situation for Maharaja, he did not take any decision about the accession of the state of Jammu and Kashmir. Another factor changed the situation when three of the four tehsils of the Gurdaspur district (which had a Muslim majority) were announced to give to India. Due to that factor, India got direct physical access to Kashmir and Kashmir's dependency on Pakistan got reduced (Leonard, 2005).

People of Poonch and Mirpur in the form of Azad forces marched along with tribesmen from KP to Srinagar to overthrow Maharaj's rule. An interim Azad government was formed in Pulandri AJK on 22 October 1947, in the context of Law-and-Order situation, on 26 October 1947, Maharaja Hari Singh acceded to India provisionally (Schofield, 2003). The tribesmen's role was controversial and detrimental to the Kashmir cause. Tribal warriors were involved in looting, raping, and pillaging. Among the victims were some Catholic nuns that brought international condemnation and disapprobation (Ahmed, 2010).

Though Pakistan had ruled out any help to Tribesmen, but many people claim that they were aided and abated by Pakistan. some accounts show that hundreds of Pandits and Sikhs were killed, and their women were raped. Forced conversions and mass exodus were also reported (Pandita, 2013). That anarchical situation gave rise to a full-scale war between India and Pakistan, since then Kashmir is heavily militarized.

\section{WHAT IS PAKISTAN-ADMINISTERED-KASHMIR/AJK?}

Pakistan-administered Kashmir or Azad Kashmir (AJK) is called with these names among others. In general, Pakistan administered Kashmir refers to the two regions of Jammu \& Kashmir administered by Pakistan. 'Azad Kashmir and Gilgit- Baltistan. In India, this region is called Pakistan administered Kashmir. However, Gilgit- Baltistan is considered separate but India still sees it as part of it. The term POK is used for 'Azad Kashmir' (Zakaria, 2018).

United Nations resolutions on Kashmir do not recognize Azad Kashmir as a sovereign state or province of Pakistan. It is considered a 'local authority' which has the responsibility for the area assigned to it under a 1949 ceasefire agreement with India (Pakistan, 2006). AJK is an area of 13,297 square kilometers with a population of 4,045,366 persons as per 2017 census reports (Bukhari, 2014).Sunni Muslims is the majority in AJK. There are three divisions, Mirpur, Muzaffarabad (Capital of AJK), and Poonch. They are further divided into eleven districts. These districts include Muzaffarabad, Neelam, Hattian Bala, Bagh, Haveli, Poonch, Sudhunutti, Kotli, Mirpur, Bhimber, and forward- kahuta. (Officially documented by AJK Government).

Pahari and Gojari are dominant spoken languages in AJK. Some stats show that 35 percent of the population speaks Gojari in Muzaffarabad and Hattian Bala districts and 30 percent speaks it in Haveli district. 50 percent of the population in these districts speaks Pahari. 63 percent of people in the Neelam district speak Pahari while 20 percent speak Kashmiri (Research, 2020).

Ceasefire, LoC

An UN-mediated ceasefire was observed by Indi and Pakistan in 1949, both States agreed on a 
ceasefire line after withdrawing military troops. But the maximalist positions on Kashmir continued to stay, as they fought another war in 1965 and 1971. It ended with the Shimla agreement in July 1972, establishing the line of control between Pakistan-controlled Kashmir and India-control Kashmir. The LoC. is 435 miles $(700 \mathrm{Km})$ long (Research, 2020). Another Ceasefire Agreement in 2003 was reached that brought relative peace to the region. However, several CFVs have been reported since then and figures have escalated rapidly. The LoC is delineated on the map and not on the ground. People cross it inadvertently and sometimes even soldiers lose track. Christophe Jaffrelot points out, infiltration and local politics is also a cause of CFVs. It is also called a "War by other means" (Jaffrelot, 2018).

\section{Implications of Cross-LoC escalations}

There are large implications of cross- LoC escalation on the local population in AJK. There are an estimated 285 villages along the LoC in Pakistan-administered Kashmir. If we compare the population living on the other side of the LoC which is smaller and more far away and dispersed, the villages on the Pakistani side are on zero line and are densely populated. They have to face the brunt of escalated tensions. This is one of the major reasons for the higher death toll

If we go through the reports and articles in mainstream media (national and international), it becomes evident that the plight of Kashmiris is usually reduced in numbers, however, some have analyzed it from a human angle. During the cross-LoC firing, the locals get to the bunkers, most of the time they get killed. Once 28 children were killed when a mortar hit a school in Neelum valley in the 1990s. This situation has made people psychologically, physically, and financially impaired. They have to remain in a situation of fear, their houses get damaged, and their livelihood gets affected (Zakaria, 2018).

Students and their education are badly affected. Many students resort to violence, radical ideologies, and other social and psychological issues. Schools remain shut for a long time in the backdrop of tensions along the Line of Control. Shahryar Ali has studied this dimension with facts and figures on educational infrastructure, how many schools got damaged, quality of learning, how is physical and mental health there and there is no infrastructure for disabled and special Childs, even in some parts, there is no hospital and ambulances to carry the injured to the hospital. People get no compensation in terms of finance for material loss.

Basic human rights are curbed. Some dissent voices (Nationalists) are banned. There are several books written by Azad Kashmiris that go against the dominant Pakistani narrative on Kashmir on the grounds of promoting anti-establishment agendas. In 2016,16 books were banned by the AJK government, which were written by mostly pro-freedom writers. Digital rights are suspended as there is no internet service in most of the areas. Cross-border trade gets stopped during escalations. People have to buy essential goods by paying high prices. A first-ever UN Human rights report on Kashmir examines the human rights violations in AJK, which are of different magnitude and are of structural nature. AJK has restrictions on freedom of expression, association, and peaceful assembly (Pakistan, 2006).

The socioeconomic toll that the local population has been bearing and still bear, cannot be just quantified. The villages very close to the border are the main stakeholders who have to bear the brunt of escalated tensions along the Line of Control. These villages are on zero line and are heavily populated. At times, they (some of them) get a settlement to other areas temporarily, but their permanent place of settlement is where they are. The houses, schools, and hospitals that are damaged due to shelling, show an economic cost that an individual has paid for a long time to build a house, how do they manage to rebuild the house. Schools that are damaged show an effect on education and quality of education. Similarly, the health units or small hospitals that are damaged have added to the miseries of the very population. How long and how many displacements are taken during heightened tensions is an indicator of a general sense of insecurity that prevails there.

This affects the family financially and the livelihood of an individual. Where do they manage to settle, most of the time they get camps somewhere to live in or they get a stay in some relative's home that is far away from the border. How do they get means of subsistence in the new settlement, if an individual gets a job there or what are the sources of his survival? Displacement affects the whole family, for example, the children who were enrolled in schools, do get admitted to the new school? 
They get frightened from tensions along the border. The senior members of the family get affected psychologically as most of the time they cannot adapt to the new environment.it becomes a mental trauma for them.

Zafar, Ashraf, and Adnan (the names have been changed to protect their identity) are working as a waiter at a canteen at Quaid-I-Azam University. They all belong to the Poonch division in AJK. Adnan belongs to the tehsil very close to the LoC. I interviewed them for this paper as I am focused on the socioeconomic implications of the LoC tensions: implications on the local population. 'I belong to the Khurshid Abad tehsil, about 30 kilometers from the border. 'Kahuta forward' is our city. I asked him, how many villages are there close to the border? He tells me, there are many villages, neza pir, sayra, kalamula, tattapani, bayri, dawarandi, buttle and chirikot. I asked, in your opinion, how much is the population there? He said the population of the whole tehsil is about 1 Lac and twenty thousand whereas the average population of every village close to the border is from twenty to twenty-five thousand.

I asked, how frequent are the shelling and firing incidents in those villages? It is almost a routine there, sometimes it happens after a week and sometimes in a month and there happens on some special dates and events like as it happened on 27 February (a recent military standoff between India and Pakistan). I asked, how does it affect the locals in terms of casualties and economically? He told me, people get killed, our houses get damaged, our cattle get killed and our crops destroyed, a mortar shell contains such kind of chemical that our fields become barren for a long time, it leaves a dark mark where it hits and even trees get black. He continues telling me about an incident that happened fifteen years ago in the Buttle area.

There was an event of marriage in a house when Indian army men infiltrated and slaughtered many people (Anam Zakariya has also mentioned in her book about such an incident, however, many respondents did not recognize the exact date of the incident) and he told me about two missiles fired at Kahuta in 1996, one was hit at a mountain, but the other was at locals killed 26 people, 40 wounded and a mosque damaged. I asked him what is the source of livelihood for people? He replied, there are very rare opportunities, infrastructure is damaged, we are at far a distance from cities, most of the people join the army, a very few get government jobs, a lot of people find work in Karachi, Lahore, Rawalpindi, and Islamabad.

A large chunk of people has been unemployed against the backdrop of security issues in Karachi, so they came back home. We do not have some opportunities in our home districts or cities. I asked whether they have to leave their houses when the tensions get heightened on the border? $\mathrm{He}$ answered, yes, the army says to evacuate our homes, we must leave our houses, asked then where do they get a settlement? He said, if anyone has enough money or relatives in cities or areas far away from the border, he will go there, but many people don't go anywhere because they don't have enough resources, or they don't want to leave their places.

Most of the people become captured in their own houses and we live in a 24-hour state of fear, every time we get cautious about shelling and firing. I asked, how does it affect the roads, schools, and health infrastructure? He answered, roads and health infrastructure are already in a state of turmoil, there are not enough facilities, however, firing does affect the infrastructure, previously 2 children in a school got killed when a mortar was hit at the school. Another school van was hit by the Indian army, killing the driver, and leaving others wounded. I asked if there are very rare facilities of health care, how do the people get their wounded too far away from hospitals? He answered, there is an army hospital at Kahuta city, but it is a very long distance from villages near the border. Many people succumb to their wounds on the way. There is no ambulance service.

Our schools remain closed for a long time, many children don't even reach matriculation, and when we have to leave our houses for a long time our children's education gets affected very badly. We don't get any money from the government as compensation until and unless it is a very popular incident, we have to build our houses as our own and sometimes we have to leave our places for more than two years. I asked him, according to your opinion, what are the reasons for the firing, and do you think the government can play a role in peace?

He replied as you know Indian army fires at us indiscriminately, so we have to respond but our army does not fire indiscriminately because on the other side of the border our Muslim brothers and sisters get affected. The matter would not be resolved until and unless Kashmir- conflict gets resolved. 
I asked if it is true that the population on the other side is far away, so they are not affected as much as our population is, which is close to the border, he answered, yes, the population on the other side is far away but we are close to the border, Indian army hits us indiscriminately. I asked him when you have to leave your homes, how does it affect you psychologically? He sighed, every family member gets affected, our elders, our children, and everybody find it very hard to adjust to a new place, we have to suffer a lot, we remain in a state of anxiety, we have to find work for survival, we borrow money and remain under debt for life.

I asked Adnan, how much do you earn by working here? He answered I earn 15,000 per month, I can't manage my expenditures with this amount, I have taken loans, there are not enough opportunities in our cities, and we do not have an opportunity of 15,000 per month earning at our place. I asked him if people have mobile phone services at border areas? He answered, no, there is no mobile service, we have to face a lot of communication difficulties.

Adnan offered me his help whenever I would like to visit his villages for interviews, at the start he was reluctant for an interview because of security issues (he was concerned if I would share his interview on media, etc.), most of the people avoid talking about implications that go against popular discourse. I took him into confidence and assured him of his anonymity. Due to time constraints, I couldn't interview some families from border areas, now settled here in Rawalpindi/ Islamabad. However, Zakariya has interviewed some families residing in Barakaho that talk about the women issues, issues of harassment, and women's role in ensuring Ceasefire.

\section{CONCLUSION}

Kashmir conflict has socioeconomic, political, and psychological implications for the local population in Pakistan-administered Kashmir. It is the local population that has had to bear the brunt of tensions along the LoC. Many people get killed, have to displace, and have a large socioeconomic toll. Being a resident of the Poonch sector I can relate to the situation. From an individual's life to the whole region is affected in some ways. Peace on LoC means a lot for the locals, UNMOGIP, India, and Pakistan can surely build it. But India's intransigence, bellicosity have been a hindrance. Locals in AJK strongly support trade along the LoC. The main source of livelihood is the people who are working abroad, largely in the Gulf States. They must stay there for more than 3 years at a stretch, leaving behind their families. Education is also affected, there are not enough institutions, the quality of education is below average, one can hardly find a good research paper on social issues in the very region. After the earthquake of 2005, many schools and colleges were not rebuilt. The AJK government argues the low budget share they get from the federal government in Pakistan. Development expenditure is low, health and other facilities are adequate. The Poonch district has only one $\mathrm{CMH}$, where the vaccine for snake/dog biting is not available and there are no facilities for major incidents. People have to travel to Rawalpindi/Islamabad, many patients succumb to their wounds on the way. Politics is also affected; many nationalist parties are labeled as Indian agents or foreign agents. They hardly get a political resonance, even they are not allowed to participate in the electoral process until and unless they agree to the clause of accession with Pakistan. There isn't enough investment despite the opportunities available in tourism. Indigenous people may get some jobs if they develop small industries or manufacturing units. A large population is consisting of young people, youth is getting radicalized in the backdrop of jihadists' influence. Digital rights of the people are also curbed, internet facilities are not available, the areas very close to the border don't even have mobile phone service. Life is hard there.

I very often encountered comments about my identity in Pakistan that Kashmiris are not loyal, they are not trustworthy. Though these are stereotypes and particular perceptions, these dispositions can be traced in the socio-economic background of Kashmiris, living in a disputed territory, having limited interactions with a diversity of people, low education and hence low exposure are the factors that make them less interactive. In the popular literature available on Kashmir, AJK has been neglected, there are three universities there, this gap can be filled by the scholars and academics in those universities, but the quality of education is as low as one can hardly find a research paper on socioeconomic, cultural, behavioral and other topics of interest. There is not a single English language newspaper and is not a single Urdu newspaper of a great repute, whereas, on the other side of the border we are familiar with Basharat Pir, Wahid Mirza and we find several English and Urdu dailies. 
Many things are neglected and missing against the backdrop of popular discourse on the Kashmir conflict. An in-depth study on the very topic can surely add some knowledge and contribute to academia. Due to time constraints, I couldn't go for that. It is also a limitation of this study. 


\section{REFERENCES}

Riley E. Dunlap and William R. Catton, Jr. (1979). Environmental Sociology. Jstor, 243-273.

Ahmed, A. (2010, March 16). The Kashmir War 1947-48. The Kashmir War 1947-48. Lahore: Daily Times.

Baig, M. (2007, September 28). Asia's Last colony. Retrieved October 17, 2020, from https://www.outlookindia.com/website/story/asia8217s-last-colony/235655

Bukhari, S. (2014, June 30). Nearly 35\% People Speak Kashmiri in Erstwhile J\&K: Study. Retrieved November 6, 2020, from http://www.risingkashmir.com/news/nearly-35-people-speakkashmiri-in-erstwhile-jk-study

Gert Spaargaren, Arthur P. J. Mol, et al. (2000). Environment and global Modernity. New Delhi: Sage Publications.

Jacob, H. (2018). The line of control: Travelling with the Indian and Pakistani Armies. New Delhi: Penguine Viking.

Jaffrelot, C. (2018, October 24). Ceasefire Violations in Kashmir: A War by Other Means? Retrieved November 6, 2020, from https://carnegieendowment.org/2018/10/24/ceasefire-violations-inkashmir-war-by-other-means-pub-77573

Khan, A. (1975). Raiders in Kashmir. Islamabad: National Book Foundation.

Leonard, T. M. (2005). Encyclopedia of the Developing World. Sue Polanka: Routledge.

Man Singh Deora, Rajinder Grover. (1991). Documents on Kashmir Problem: Discussion of the IndiaPakistan Question in the Security Council meeting. New delhi: Discovery Publishing House.

Nasreen Akhtar and Daniel A. Métraux. (2013). Pakistan is a Dangerous Place for Women. International Journal on World Peace, Vol. 30, No. 2 (JUNE 2013), 35-70. Retrieved from https://www.jstor.org/stable/24543779

Nikolaus Eder, Marcelo Jenny, Wolfgang C. Muller. (2016). Manifesto functions: How Party Candidates View and Use their Party's Central Policy Document. Science Direct, 75-87.

Pakistan, H. R. (2006, September 14). With Friends like These, Human Rights Violations in Azad Kashmir. $\quad$ Retrieved October 31, 2020, from https://www.hrw.org/reports/2006/pakistan0906/pakistan0906webwcover.pdf

Pandita, R. (2013). Our Moon Has Blood Clots: The Exodus of the Kashmiri Pandits. New Delhi: RHI.

Paul R. Brass. Newbury Park Calif. (1991). Ethnicity and Nationalism: Theory and Comparison . Sage Publications, 358.

Research, C. E. (2020, March 26). Kashmir Fast Facts. Retrieved November 3, 2020, from https://edition.cnn.com/2013/11/08/world/kashmir-fast-facts/index.html

Robert Harmel, Alexender C.Tan, Kenneth Janda, Jason Matthew Smith. (2016). Manifestos and the "Two Faces" of Parties: Addressing both Members and Voters with one Document. Sage Journals, 278-280.

S Cotgrove; John Wiley, Chichester, Sussex. (1983). Catastrophe or Cornucopia: The Environment, Politics, and the Future. Jstor, 131-142.

Schofield, V. (2003). Kashmir in Conflict: India, Pakistan and the Unending War. London: Bloomsbury Academic.

Snedden, C. (2013). The Untold Story of the people of Azad Kashmir. Karachi: Oxford University Press.

Sri Nandan Prasad, Dharam Pal. (2005). History of Operations in Jammu \& Kashmir, 1947-48. Natraj Publishers.

Zakaria, A. (2018). Between the great divide a journey into Pakistan-administered Kashmir. Noida: HarperCollins Publishers India. 